\title{
Vanishing Points: Walter Benjamin and Karel Teige on the Liquidations of
}

\section{Aura}

\section{The Aura of Originality}

The vanishing of the aura is the most celebrated postulate not only in Walter Benjamin's most celebrated essay, 'Das Kunstwerk im Zeitalter seiner technischen Reproduzierbarkeit' (hereafter the 'artwork essay'), but indeed anywhere in his writings. Even stating this fact became long ago a mechanical gesture. ${ }^{1}$ The artwork essay is routinely characterized as 'a scandal and a provocation', as overturning established aesthetic beliefs so radically as to achieve epochal status. $^{2}$ In a major recent history of German literature, for

1 Thirty years ago Werner Fuld claimed 'es scheint, als habe von allen Gedanken Benjamins gerade dieser unzugänglichste Eingang gefunden in die sich täglich reproduzierende Sprache (nicht in das Denken) der Kulturbeflissenen, als wirkte Benjamin nach in diesem einzigen Begriff'; Fuld, 'Die Aura: Zur Geschichte eines Begriffes bei Benjamin', Akzente 26/3 (1979), 352-370 (p. 353). See also Burkhardt Lindner, 'Benjamins Aurakonzeption: Anthropologie und Technik, Bild und Text', in Uwe Steiner (ed.), Walter Benjamin 1892-1940, zum 100. Geburtstag (Bern: Lang, 1992), pp. 217-48 (p. 217). Examining this essay now seems practically to require a prefatory apology: see, e.g., Miriam Bratu Hansen, 'Room-for-Play: Benjamin's Gamble with Cinema', October 109 (2004), 3-45 (p. 3).

2 Michael W. Jennings, 'The Production, Reproduction, and Reception of the Work of Art', in Walter Benjamin, The Work of Art in the Age of its Technological 
example, Benjamin's theses are described as 'terrifying', 'bordering on heresy', and as 'shred[ding] the fabric of the most cherished beliefs about art'.3 Even unabashedly hostile commentators feel compelled to pay 'homage ... to the essay's originality'.4 Benjamin himself encourages such a view when, at the outset of the essay, he claims to provide 'neu in die Kunsttheorie eingeführten Begriffe' and elsewhere (in a letter to Gershom Scholem) expresses anxiety lest

Reproducibility, and Other Writings on Media, ed. by Michael W. Jennings, Brigid Doherty, and Michael Y. Levin (Cambridge, MA: Harvard University Press, 2008), p. 14 .

3 Lindsay Waters, 'The Machine Takes Command', in David E. Wellbery (ed.), $A$ New History of German Literature (Cambridge, MA: Harvard University Press, 2004), p. 791. See also Andreas Huyssen's earlier claim that '[...] Benjamin sees [cultural] change developing out of modern reproduction techniques, which drastically affect the inner structure of art. Here lies the importance of Benjamin for a materialist aesthetics still to be written'; Huyssen, After the Great Divide: Modernism, Mass Culture, Postmodernism (Bloomington: Indiana University Press, 1986), p. 153.

4 Antoine Hennion and Bruno Latour, 'How to Make Mistakes on So Many Things at Once-and Become Famous for It', in Hans Ulrich Gumbrecht and Michael Marrinan (eds), Mapping Benjamin: The Work of Art in the Digital Age (Stanford: Stanford University Press, 2003), p. 91. 
his ideas be stolen before he has had the chance to publish them.5 This consensus regarding the importance and originality of Benjamin's account of the decline of aura has helped make the artwork essay 'probably the most frequently cited and most intensely debated essay in the history of the academic humanities of the twentieth-century'. 6

None the less, the intense fascination generated by the artwork essay has engendered a continual re-forgetting of what should be an obvious fact: Benjamin's major theses are brilliantly formulated, have a unique philosophical resonance, and occupy a crucial position in the larger edifice of his thought, but they are hardly original. The term 'aura' may be Benjamin's, but the idea of its vanishing is not. Indeed, one might speculate that part of what has made the artwork essay such a touchstone for debates on modern, postmodern and contemporary aesthetics is the way Benjamin lends such great conceptual depth to claims that were becoming commonplace even when he completed the first version of the essay in late 1935. To acknowledge this is by no means to question the fundamental importance of Benjamin's text. But it should warn against uncritical identification of Benjamin's liquidationist claims as the site of the

5 This phrase appears in all three extant German versions of the essay: see Walter Benjamin, Gesammelte Schriften, ed. by Rolf Tiedemann and Hermann Schweppenhäuser, 7 Vols. (Frankfurt a.M.: Suhrkamp, 1991) (hereafter 'GS' followed by a volume number), Vol. 1, pp. 435 and 473, and Vol. 7, p. 350. The letter to Scholem is quoted in $G S$ 1, p. 983 .

6 'Editors' Preface', in Gombrecht and Marrinan (eds), Mapping Benjamin, xiii. 
essay's greatest originality. Similar claims had been raised forcefully over at least the decade and a half preceding Benjamin's text, and the artwork essay should thus be read as responding to rather than culminating-let alone inventing-that tradition. ${ }^{7}$ Critical re-examination of the liquidationist interpretation becomes even more necessary in view of the often fundamentally opposed positions Benjamin set forth in other texts written more or less simultaneously with the artwork essay. Only once these two contexts have been taken into account can one identify where the heresies of the artwork essay truly lie. ${ }^{8}$

7 This only includes arguments connecting the decline of aura to developments in technological reproduction. If one also includes 'idealist' versions of the thesis then the tradition is far older: as Jürgen Habermas pointed out, 'Hegel already announced the loss of aura in his Lectures on Aesthetics'; Jürgen Habermas, 'Walter Benjamin: Consciousness-Raising or Rescuing Critique', trans. by Frederick Lawrence, in Gary Smith (ed.), On Walter Benjamin: Critical Essays and Recollections (Cambridge, MA: MIT Press, 1988), p. 103.

8 In her magisterial analysis of the artwork essay, Miriam Bratu Hansen has 'put into question the liquidationist tenor of the essay [...] and, by implication, the facile reproduction of this tenor in the essay's standard reception'. But while Hansen focuses on Benjamin's turn to film as 'the only medium that might yet counter the devastating effects of humanity's "bungled [verunglückte] reception of technology", which had come to a head with World War I', I wish to explore how the artwork essay harbours a veiled critique of the liquidationist logic it invokes. See Miriam Bratu Hansen, Cinema and Experience: Siegfried 
Tracing the extent of Benjamin's reliance upon established liquidationist claims in the artwork essay, therefore, is not an exercise in debunking. Rather, such contextualization allows more precise identification of Benjamin's relation to the avant-garde discourse he invokes, and reveals a perspective that the heaped declarations of the essay's scandalous nature have obscured. Claims for the epochal status and ongoing relevance of the artwork essay generally emphasize its prognostic value: how the essay forecast developments extending well beyond Benjamin's own historical moment. The focus on prognosis may seem natural-after all, Benjamin himself writes of the 'prognostische Anforderungen' of the essay ( $G S$ 7, p. 350). None the less, broader contextualization provides grounds not only for suspicion of such a prognostic reading, but also for understanding the main analytic gesture of the essay less as prognosis of the future and more as diagnosis of Benjamin's present. One can cite Benjamin in support of this approach as well, for in letters to friends and colleagues Benjamin repeatedly described the essay as forensics rather than forecast: the essay, he writes, traces the 'Signatur' of its present and aims at the 'genaue Fixierung des Standorts der Gegenwart'. 9

Reading the artwork essay as a diagnostic rather than prognostic document brings several advantages. First, it avoids attributing to the essay a

Kracauer, Walter Benjamin, and Theodor W. Adorno (Berkeley: University of California Press, 2012), pp. 83 and 79.

9 Letters to Max Horkheimer from October 1935 and to Werner Krafft from 27 December 1935, reproduced in $G S$ 1, pp. 983 and 984 respectively. 
model of continuous temporal extension that is inseparable from the concept of prognosis and that Benjamin systematically critiques elsewhere in his work. Second, it allows a more nuanced formulation of how the essay combines celebratory and critical stances towards the developments it describes (which are often understood as revealing a fundamental contradiction or ambivalence in Benjamin's thought). Third, it avoids attributing to the essay primacy for liquidationist claims that were already well established at the time it was written. By championing claims that constituted the Jüngstvergangene, or most recent past of avant-garde theory, the artwork essay acknowledges simultaneously the efficacy and the historical boundedness of the liquidationist position. Without explicitly criticizing that position, I will argue, Benjamin acknowledges that it can appear in the conceptual mold of a Wunschbild or wish-image belonging to his own historical moment. Because the wish-image of the vanishing aura characterizes the present in which the artwork essay is embedded, Benjamin himself cannot escape its seductive power. Yet as wish-image it also marks that moment as historically determined, delimited, and thus inherently partial. The liquidationist claims the essay is so often taken to originate, therefore, function less as materialist prognosis of a destination just become visible on the horizon of the future, and more as diagnosis of a thought-pattern of Benjamin's present: a wish-image that no thinker (or at least none unburdened by regressive ideals) could avoid. This sense of the 'unavoidability' of the wish-image lends the artwork essay celebratory and critical vectors that are not contradictory but rather self-reflexive. 
The interpretive perspective I propose here is neatly expressed in an image Benjamin used to describe the relation of the artwork essay to his other work (specifically the historical construction undertaken in the Passagen-Werk): 'Diesmal handelt es sich darum, den genauen Ort in der Gegenwart anzugeben, auf den sich meine historische Konstruktion als auf ihren Fluchtpunkt beziehen wird.'10 This image of the vanishing point is curious, for it presumes a counterintuitive relation between foreground and background. One does not look through the foreground of the present out into the background of the past (as a more traditional image of the historical gaze would posit) nor does one look through the foreground of the present out into the future emerging on the distant horizon (as the image of prognosis would require). Rather, historical 'background' forms Benjamin's foreground; and the present-that which is temporally closest-is located in the background, at the vanishing point. If it is true that 'Benjamin denkt in Bildern', ${ }^{11}$ it is equally true that aspects of Benjamin's thought can be grasped mimetically through images that Benjamin himself invoked only fleetingly. The present essay explores the diagnosis of the wish-image inhering in the artwork essay through the conceptual figure of the vanishing point: a point marking both a hypothetical state in which aura has vanished, as well as Benjamin's critical distance from the liquidationist thoughtpatterns of his own present.

10 From the same letter to Max Horkheimer, cited in GS 1, p. 983.

11 Ansgar Hillach, 'Dialektisches Bild', in Michael Opitz and Erdmut Wizisla (eds), Benjamins Begriffe (Frankfurt a.M.: Suhrkamp, 2000), p. 189. 
Benjamin's intellectual debts have been carefully explored. Much has been written on various sources for the concept of the aura. The term contains clear reverberations of the discourse on 'human aura' in fin-de-siècle mysticism and spiritualist movements (such as theosophy and anthroposophy, which Benjamin abhorred), of early Romantic or older notions of the 'schöner Schein', or even of medieval mysticism and the Kabbalah. ${ }^{12}$ Commentators have traced earlier

12 See, e.g., Hansen, Cinema and Experience, chapter four; Josef Fürnkäs, 'Aura', in Opitz and Wizisla (eds), Benjamins Begriffe, pp. 95-146; Fuld, 'Die Aura'; Wolfgang Braungart, 'Walter Benjamin, Stefan George, und die Frühgeschichte des Begriffs der Aura', Castrum Peregrini 46/230 (1997), 38-51; Gary Smith, 'A Genealogy of “Aura”: Walter Benjamin’s Idea of Beauty', in Carol G. Gould and Robert S. Cohen (eds), Artifacts, Representations, and Social Practice: Essays for Marx Wartofsky (Dordrecht: Kluwer, 1994), pp. 105-119; Marleen Stoessel, Aura, das vergessene Menschliche: Zu Sprache und Erfahrung bei Walter Benjamin (Munich: Carl Hanser Verlag, 1983); Birgit Recki, Aura und Autonomie: Zur Subjektivität der Kunst bei Walter Benjamin und Theodor W. Adorno (Würzburg: Königshausen \& Neumann, 1988), pp. 49ff.; Guy Hocquenghem and René Schérer, 'Formen und Metamorphosen der Aura', in Dietmar Kamper and Christoph Wulf (eds), Das Schwinden der Sinne (Frankfurt a. M.: Suhrkamp, 1984), pp. 75-86; Hans Robert Jauß, 'Spur und Aura: Bemerkungen zu Walter Benjamins "Passagen-Werk", in Studien zur 
appearances of the term or at least the concept in Benjamin's work from the 1920s. ${ }^{13}$ Benjamin's particular use of the concept of 'aura' thus emerges from a long-standing theological tradition that gives the term an immediate ring, an intuitive clarity, despite the notoriously thorny difficulties that ensue when one tries to pin down the details of Benjamin's account. This might suggest that, at least in part, the originality of Benjamin's essay lies less in the concept of aura itself than in his application of the term to aesthetics and in his claim about its vanishing under modern technological conditions. ${ }^{14}$

Yet even here precursors are evident. For one thing, Benjamin 'had happily stolen' on a broad level from Romantic and post-Romantic nostalgic discourses on lost aesthetic harmony; indeed it has even been suggested that Benjamin was specifically influenced by conservative critiques of mechanized culture during World War I.15 Benjamin's essay, however, is far less pessimistic

Epochenwandel der ästhetischen Moderne (Frankfurt a.M.: Suhrkamp), pp. 189215 .

13 The most important are 'Kleine Geschichte der Photographie' (GS 2, pp.368$85)$ and the report on hashish (GS 6, p. 588).

14 Hansen, however, argues that the 'narrowly aesthetic understanding of aura' has impoverished the concept, and that only attention to the wider resonance of the term allows understanding the role of the term in Benjamin's theory of modern experience (Cinema and Experience, p. 104).

15 Robert Kaufman, 'Aura, Still', in Andrew Benjamin (ed.), Walter Benjamin and Art (London: Continuum, 2005), pp. 121-147 (p. 122). Arnd Bohm has 
about cultural change under modernity than such sources. Thus it is rather the interwar avant-garde movements such as Dada, Constructivism, and Surrealism, with their exploration and celebration of the non-auratic tendencies of the modern artwork, that appear more plausible an influence on Benjamin. ${ }^{16}$ These movements represented various forms of 'attack on [...] the very notion of art as

argued that an early essay in Kulturkritik by Adolf Behne influenced Benjamin; see Bohm, 'Artful Reproduction: Benjamin's Appropriation of Adolf Behne's “Das reproduktive Zeitalter" in the Kunstwerk-Essay', The Germanic Review 68.4 (1993), 146-155.

16 In Petr Málek's words, 'the epochal significance [of the artwork essay] should not disguise the fact that, while the essay grasps the problem of technical/mass (re)production of the artwork in all its complexity and contradictoriness, this problem had occupied avant-garde artists and theoreticians since the 1910s'; Petr Málek, 'Masová (re)produkce', in Josef Vojvodík and Jan Wiendl (eds), Heslář české avantgardy: Estetické koncepty a proměny uměleckých postupů v letech 1908-1958 (Prague: Opera Facultatis philosophicae Universitatis Carolinae Pragensis, 2011), p. 182. See also Krzysztof Ziarek, 'The Work of Art in the Age of Its Electronic Mutability', in Andrew Benjamin (ed.), Walter Benjamin and Art, pp. 209-225; John McCole, Walter Benjamin and the Antinomies of Tradition (Ithaca, NY: Cornell University Press, 1993), pp. 160-61; Michael Müller, Architektur und Avantgarde: ein Vergessenes Projekt der Moderne? (Frankfurt a.M.: Syndikat, 1984), pp. 98-147; as well as the references in note 22 below. 
an institution' in an attempt to 'shed the aesthetic construction of art'.17 Benjamin himself described Dada as a major precursor for the idea of the withering of aesthetic aura through its attempt to create effects that would eventually be achieved most directly and radically only through the new medium of film. Dada represented an 'anticipation', as it were, of coming changes in aesthetic perception, and a frantic or perhaps frustrated attempt to instigate those changes before the necessary technical media had developed. The specific changes that Benjamin felt Dada had presaged were the dissolution of the attitude of contemplative immersion (Versenkung) in the reception of the artwork and, primarily, the 'rücksichtslose Vernichtung der Aura' (GS 7, p. 379). Both of these changes were implicit in the Dadaist 'Entwürdigung ihres Materials': Dada's use of linguistic detritus (such as nonsense words and obscene exclamations) and fragments from everyday life (shirt buttons, tram tickets mounted onto collages) represented for Benjamin a radical critique and indeed mockery of the auratic artwork, with its claim to uniqueness and elevation. The 'Wortsalat' (ibid.) of a Dadaist poem or collage thus in effect attempted to brand itself as a reproduction (or to achieve the effect that, according to Benjamin, film as the ultimate reproducible artwork would soon achieve) even though in a literal sense most of these Dadaist products still utilized more or less traditional modes of production.

But if Dada represents the intuitive anticipation of emerging tendencies, other avant-garde innovators not discussed in the artwork essay enacted quite

17 Ziarek, 'The Work of Art', p. 212. 
consciously much of what that text analyzes. In particular many figures associated with International Constructivism adhered to the ideal of, and produced radical strategies for carrying out, non-auratic cultural production. ${ }^{18} \mathrm{~A}$ telling example is the pair of 'telephone pictures' Laszlo Moholy-Nagy produced in 1922, titled 'EM 1' and 'EM 2'. To make these works Moholy-Nagy simply gave instructions to a sign painter over the telephone, specifying coordinates and tones of color fields, which were then printed on a steel sheet as if on a piece of graph paper. The elimination of unique authorial intervention, the anti-auratic nature, and the immanence of technical reproducibility to this procedure are clear. ${ }^{19}$

18 Frederic J. Schwartz writes that ideas of the kind central to the Artwork essay's distracted, productive expert were clearly quite current already in the 1920 among a certain group of artists'; Schwartz, 'The Eye of the Expert: Walter Benjamin and the Avant-Garde', Art History 24 (2001), 401-444 (p. 412). And in Eckhardt Köhn's words, 'das Thema der technischen Reproduktion von Kunstwerken, das Benjamin angreift, ist ein altes Thema des Konstruktivismus'; Eckhardt Köhn, “Nichts gegen die Illustrierte!”: Benjamin, der Berliner Konstruktivismus, und das avantgardistische Objekt', in Detlev Schöttker (ed.), Schrift Bilder Denken: Walter Benjamin und die Künste (Frankfurt a.M.: Suhrkamp, 2004), pp. 48-69 (p. 64).

19 Krisztina Passuth claims that these telephone pictures 'obviously provided inspiration for Walter Benjamin's [artwork] essay dating from a slightly later period'; Passuth, Moholy-Nagy (New York: Thames \& Hudson, 1985), p. 33. See 
Benjamin's theory of the decline of auratic art thus took fundamental inspiration from the waves of revolt against aesthetic autonomy produced by the historical avant-garde movements during and immediately following World War I. While the importance of these precedents is conspicuous, commentators rarely seem bothered by the time-lag between the precedent and Benjamin's essay itself. ${ }^{20}$ Yet given that Benjamin's account of the decline of aura as a result of

also Schwartz, 'The Eye of the Expert', p. 428. Manfredo Tafuri, without discussing the telephone pictures, associates Moholy-Nagy's 'technological utopia' with Benjamin's artwork essay; see Tafuri, The Sphere and the Labyrinth: Avant-Gardes and Architecture from Piranesi to the 1970s, trans. by Pellegrino d'Acierno and Robert Connolly (Cambridge, MA: MIT Press, 1987), pp. 142-43. Moholy-Nagy's 1922 essay on 'Production-Reproduction' also foreshadows elements of both the artwork essay as well as Benjamin's 'The Author as Producer' (1935) (Krisztina Passuth's translation is contained in Timothy O. Benson and Éva Forgács (eds), Between Worlds: A Sourcebook of Central European Avant-Gardes, 1910-1930 (Cambridge, MA: MIT Press, 2002), pp. 454-55).

20 Peter Bürger's classic Theory of the Avant-Garde, trans. by Michael Shaw (Minneapolis: University of Minnesota Press, 1984) set an example for discussing Benjamin in the context of avant-garde movements such as Dada without reflecting on the time-lag between them. Ziarek (pp. 211-214) represents a recent example. Passuth also glosses over the 13-year gap between Moholy-Nagy's telephone pictures and the artwork essay (see previous note). 
technical reproducibility has been traced back to sources from the early 1920 or or mid-1910s (if not earlier), it is clear that the epochal originality of Benjamin's claims in 1935 cannot possibly lie in the liquidationist moments of the essay, as is so often maintained. Attempts to deepen our understanding of Benjamin's own accelerating interest during the mid-1920s in the European avant-garde, and its profound effect on the shape of his work, offer some clarification here, since they reveal that Benjamin was himself active (albeit rather peripherally) in some of the movements that inspired his later essay. ${ }^{21}$ Recent scholarship has focused attention, for example, on Benjamin's contacts with the G-Group in Berlin, on his publications in the avant-garde revue $i 1 O$, and on his incorporation of avant-

${ }^{21}$ This interest may originate even earlier since, according to Gershom Scholem, Benjamin was neighbors and met with Hugo Ball and Emmy Hennings in Bern in 1917-1919; see Scholem, Walter Benjamin-Die Geschichte einer Freundschaft (Frankfurt a. M.: Suhrkamp, 1975), p. 101. As Detlev Schöttker points out, this early contact with Zürich Dadaists would likely have made Benjamin receptive to the Dada movement just becoming active in Berlin upon his return, and consequently also with the Berlin Dadaists' propagation of Russian and International Constructivism; see Schöttker, Konstruktiver Fragmentarismus: Form und Rezeption der Schriften Walter Benjamins (Frankfurt a. M.: Suhrkamp, 1999), pp. 152-3 and 159. This early (and short-lived) alliance between Dada and Constructivism culminated in the International Congress of Constructivists and Dadaists in September 1922 in Weimar. 
garde techniques into works like Einbahnstrasse. ${ }^{22}$ Yet the question remains regarding the 'belatedness' of Benjamin's theory of the decline of aura. ${ }^{23}$

${ }_{22}$ See in particular Detlef Mertins and Michael W. Jennings, 'Introduction: The G-Group and the European Avant-Garde', in Mertins and Jennings (eds), G: An Avant-Garde Journal of Art, Architecture, Design and Film, 1923-1926 (London: Tate, in association with the Getty Research Institute, 2010), pp. 3-20 (esp. pp. 8 and 16); Frederic J. Schwartz, Blind Spots: Critical Theory and the History of Art in Twentieth-Century Germany (New Haven: Yale University Press, 2005), chapter two, esp. pp. 39-51; Michael Jennings, 'Walter Benjamin and the European Avant-Garde', in David S. Ferris (ed.), The Cambridge Companion to Walter Benjamin (Cambridge: Cambridge University Press, 2004), pp. 18-34; Köhn, “Nichts gegen die Illustrierte!”; Schwartz, 'The Eye of the Expert'; Schöttker, Konstruktiver Fragmentarismus, esp. pp. 156-172; Detlev Schöttker, 'Reduktion und Montage: Benjamin, Brecht, und die konstruktivistische Avantgarde', in Klaus Garber and Ludger Rehm (eds), global benjamin 2 (Munich: Wilhelm Fink Verlag, 1999), esp. pp. 750-51.

23 Hansen argues that Benjamin's 'tactical belatedness' reached back to a moment of unrealized potential before the mastery of false auratic culture by fascism and the 'surrendering [of] important Marxist positions' by the Popular Front: 'It is because Benjamin was so acutely aware of the politically and aesthetically retrograde and dangerous uses of the technological media [...] that he resumed the perspective of the 1920 s avantgarde' (Cinema and Experience, p. 87, 77, and 88). This may be true, but underplays the critical reevaluation 
Benjamin himself proposes a resolution. He implies that his reflections in the artwork essay represent a qualitatively different phase from the earlier avantgarde movements. While Dada may have anticipated the developments described in his essay, it did so largely in ignorance of the developmental forces to which it was responding. Dada enacted one of the first overt manifestations of the decline

implicit in Benjamin's return to this earlier moment. Maria Gough has also discussed 'Benjamin's belatedness' in 'Paris, Capital of the Soviet Avant-Garde', October 101 (2002), 53-83 (esp. pp. 76-83), and in turn cites Hal Foster, The Return of the Real: The Avant-Garde at the End of the Century (Cambridge, MA: MIT Press, 1996), p. 275, note 4. Gough's discussion, however, pertains to 'The Author as Producer' and addresses the belatedness issue primarily through historical contextualization specific to that essay. Interestingly, the artwork essay's belatedness as film theory is often noted: Eva Geulen acknowledges that 'Benjamin's text arrives relatively late in the history of the theory of film' (Geulen, 'Under Construction: Walter Benjamin's 'The Work of Art in the Age of Mechanical Reproduction', in Richter (ed.), Benjamin's Ghosts, 122); Lutz Koepnick, in his Walter Benjamin and the Aesthetics of Power (Lincoln, NB: University of Nebraska Press, 1999), p. 143, points out that many of Benjamin's formulations are 'curiously out of synch with the developments of film technology' (specifically the rise of the sound picture); and Miriam Hansen, in her 'Benjamin, Cinema, and Experience: "The Blue Flower in the Land of Technology"', New German Critique 40 (1987), p. 182, connects the 'belated moment of the Artwork essay' with its function as redemptive criticism. 
of aura, but-like all true action-this occurred spontaneously and, as it were, blindly in the heat of the moment. By contrast, Benjamin implies, his artwork essay represents the intellectual mastery of that originary moment: a phase of reflection that became possible 'erst heute' ( $G S 7$, p. 350) once the incipient historical vector to which Dada responded revealed its true direction through the development of film as a medium. ${ }^{24}$ Benjamin states that Dada's prescient 'Intentionen’ ‘ihm [Dada] selbstverständlich in der hier beschriebenen Gestalt nicht bewußt sind' (GS 7, p. 379). The artwork essay, therefore, represents the coming to consciousness of what, in Dada and other historical avant-garde movements, constituted an unconscious, instinctually felt response to changes in relations of production. Such a scheme of originary action versus conscious reflection relativizes Benjamin's debts to the historical avant-garde by attributing primacy to him at least on the level of theoretical elaboration. This scheme may well represent an unspoken academic consensus on the issue of the avant-garde precedents for the artwork essay. ${ }^{25}$ Yet if one pauses to examine just how far the

24 Benjamin's failure to explain what historical or material forces could have produced Dada's alleged 'anticipation' of effects that fully revealed themselves at a later phase makes Bürger sceptical of Benjamin's account of aura and leads him instead to emphasize Benjamin's concept of allegory as most relevant for the theory the historical avant-garde (Theory of the Avant-Garde, pp. 29 and $68 \mathrm{ff}$.). 25 Huyssen's influential account accepts Benjamin's own (idiosyncratic) explanation that 'it took much longer for the production relations of capitalist society to make an impact on the superstructure than it took them to prevail at 
theoretical or reflective phase of the avant-garde attack on aesthetic autonomy had in fact reached by the early 1920 , then even this scheme becomes shaky.

Here is where the career of Karel Teige (1900-1951), the leading theorist of the interwar Czech avant-garde, takes on particular relevance. Unofficial spokesperson for Devětsil, the largest and most significant Czech avant-group in the 1920 , Teige provided the center of gravity for various avant-garde activities ranging from literature, architecture, visual media from painting to typography, and theater. He was also interwar Czechoslovakia's most active avant-garde ambassador, maintaining close contacts in Paris, Berlin, and Moscow, among other centers. He was enormously prolific both at home and abroad. His texts neither attain nor aspire to the philosophical heft of Benjamin's, but Teige was a stringently logical thinker whose interventions even in passing cultural-political debates presupposed a systematic and synthesizing theory of avant-garde production, which he also viewed as inherently linked to Marxist political engagement. ${ }^{26}$ During the early 1920 Seige became a fierce proponent of International Constructivism, and his reputation as one of the most uncompromising critics of 'aesthetic' approaches to modernist architecture was

the basis, so much longer that they could only be analyzed in the 1930s' (After the Great Divide, p. 153).

26 Teige was a far more orthodox Marxist than Benjamin, although he never joined the Czechoslovak Communist Party. After 1948 Teige was subject to a vicious official smear campaign as the embodiment of decadent Trotskyite modernism. 
secured during a high-profile polemic with Le Corbusier from 1929. But surprisingly, Teige simultaneously propagated a movement he termed Poetism, a Czech specificum calling for ludic spontaneity, 'the liberation of instincts [and] the development of the productive drive'. ${ }^{27}$ In the early 1930s, as Poetism became increasingly focused on the function of the unconscious, and as French Surrealists around André Breton became increasingly vociferous about their Marxist orientation, Teige saw the two movements as naturally merging, and from 1934 he became a leading figure in the recently founded Czech Surrealist Group. ${ }^{28}$

Most important here, however, is that beginning in the early 1920 s Teige articulated a theoretical position that clearly anticipates many of the central

27 Karel Teige, 'Poesie pro 5 smyslů, čili druhý manifest poetismu', in his Svět, který voní (Prague: Odeon, 1931), p. 237. Some of the complexities of Teige's Constructivism/Poetism dualism, as well as the debate with Le Corbusier, are examined in Peter Zusi, 'The Style of the Present: Karel Teige on Constructivism and Poetism', Representations 88 (2004), 102-124; and 'Tendentious Modernism: Karel Teige's Path to Functionalism', Slavic Review 67 (2008), 82139.

28 For Teige's account of this development, see his 'Deset let surrealismu' in Karel Teige, Výbor z díla, ed. by Jiř́ Brabec, Vratislav Effenberger, Květoslav Chvatík and Robert Kalivoda, 3 Vols. (Prague: Československý spisovatel, 19661994) (hereafter 'Výbor' followed by a volume number), Vol. 2, pp. 139-89. The Czech Surrealist Group was founded in 1934 by the poet Vítězslav Nezval. 
claims of Benjamin's artwork essay.29 The point of bringing Teige into the discussion is certainly not to claim that Benjamin was scooped by fourteen years or so, and thus to transfer the aureole of originality from a canonical to a lesserknown figure. Teige himself made no claims to originality. He rather saw himself as a conduit of developments from various sources, freely taking over ideas and slogans from other figures (for example from Soviet Constructivists active in Berlin such as El Lissitzky and Ilya Ehrenburg, who themselves were transmitting and transforming currents from Moscow), and often rehashing his own work by recombining articles from avant-garde journals into books. He saw himself as a discursive analyst, synthesizer, and propagator of international trends that were already widespread by the early 1920s. That Teige felt his major claims were already becoming widely established, however (at least among 'progressive' figures) is precisely the point. There is no need to fetishize originality, and Benjamin's essay does not lose its force through deeper contextualization of its claims. Yet such contextualization does suggest interpretive conclusions different from the aesthetic 'heresies' so often celebrated. Accordingly, the next section of this essay will examine several of Teige's early texts in order to recover more of the conceptual field of early International Constructivism and show that many of the most famous claims in the artwork essay appear (albeit in less coherent and less resonant form) in Teige's texts of the early and mid-1920s. Section three will then examine where

29 The Teige-Benjamin comparison has attracted almost no scholarly attention. Málek's 'Masová (re)produkce' (see note 16) is an insightful exception. 
Benjamin's thought departs from the liquidationist line put forward by Teige, and will turn to the theoretical implications for interpreting the artwork essay.

\section{The Liquidations of Aura}

There is no evidence that Benjamin and Teige knew, let alone engaged with, each other's work. The closest their names seem to have come during their lifetimes was in the pages of the short-lived avant-garde journal G. Hans Richter, the driving force behind the journal, wrote a brief gloss on Prague, Teige and Devětsil's breakthrough anthology Život II ('I know of no illustrated book that is more abreast of its time' wrote Richter) which appeared on the page directly preceding Benjamin's translation of a short essay on photography by Tristan Tzara. ${ }^{30}$ Although there is no evidence of direct contact, Benjamin and Teige did share a constellation of intellectual orientation points and sources of inspiration. Moholy-Nagy (active for a time in the G-Gruppe and then in the journal i1o) went on to become a central figure in the Bauhaus after 1923. Teige observed developments in the Bauhaus closely: his initial skepticism regarding what he regarded as aestheticist elements of the program under Walter Gropius' leadership turned to enthusiasm when Hannes Meyer, with whom Teige was friends, became director in 1928. Meyer's radical functionalism and uncompromising scientism (as well as his stricter Marxism) were close to the intellectual line Teige had propagated since the early 1920 . Indeed, Teige was

3о See Mertins and Jennings (eds), G: An Avant-Garde Journal of Art, Architecture, Design and Film, pp. 140-141. 
among the guest lecturers whom Meyer soon invited to the Bauhaus to help cultivate this new, sober orientation-the logical positivists Rudolf Carnap, Herbert Feigl, and Hans Reichenbach were also among the more famous guestsand as external Dozent Teige delivered a lecture cycle in Dessau in early 1930 on the sociology of architecture. ${ }^{11}$ A course by Teige on material and technical innovations in contemporary literature, poetry and typography (planned for the fall 1930 semester) did not take place due to Meyer's forced resignation. ${ }^{22}$ A book by Teige entitled Tschechische Kunst (which never materialized) was included in the original publication plan that Moholy-Nagy and Walter Gropius drew up for

31 Teige set forth his views on the Bauhaus in 'Ten Years of the Bauhaus' in Karel Teige, Modern Architecture in Czechoslovakia, trans. by Irena Žantovská Murray and David Britt (Los Angeles: Getty Research Institute, 2000), pp. 317-29. Czech original: 'Deset let Bauhausu', in Výbor 1, pp. 477-86. Teige’s Dessau lectures were published under the title 'K sociologii architektury' in the journal ReD III/67 (1930), 161-223, and then in book form (Prague: Odeon, 1930). On the philosophers' visits in Dessau, see Peter Galison, 'Aufbau/Bauhaus: Logical Positivism and Architectural Modernism', Critical Inquiry 16 (1990), 709-752 (pp. 718-720).

32 See Vratislav Effenberger, 'Nové umění', in Teige, Výbor 1, p. 615; and Cohen, 'Introduction', in Modern Architecture in Czechoslovakia, pp. 17-18. In August 1930 Teige ended his collaboration with the Bauhaus in protest against Meyer's treatment and wrote a series of articles on the Meyer case and 'the poisonous gas of reaction' (see the bibliographic references in Výbor 1, p. 571). 
the series of Bauhausbücher in the mid-twenties and which, among titles by figures such as Kandinsky, van Doesburg, Malevitsch, and Mondrian, included Moholy-Nagy's own, seminal 1925 book Malerei, Photographie, Film. MoholyNagy's experiments and pronouncements on photography were important enough for Benjamin to quote them at some length in his 'Kleine Geschichte der Photographie'.33 Benjamin, as is well known, was fascinated not only by the Bauhaus but also by the modernist architectural theories of Siegfried Giedion and Adolf Behne, as well as by the ideal of glass architecture as described by Paul Scheerbart.34 Teige's own work on architectural theory was firmly located within

33 On Teige's planned contribution to the Bauhausbücher, see Passuth, MoholyNagy, p. 43. Benjamin's citations of Moholy-Nagy are in $G S$ 2, p. 382 and (unattributed) p. 385. See also Brigid Doherty, 'Photography, Typography, and the Modernization of Reading', in A New History of German Literature, esp. pp. 733-34; Frederic Schwartz, 'The Eye of the Expert', p. 403; and Eleanor M. Hight, Picturing Modernism: Moholy-Nagy and Photography in Weimar Germany (Cambridge, MA: MIT Press, 1995), p. 3.

34 See, e.g., Heinz Brüggeman, 'Walter Benjamin und Siegfried Giedion oder die Wege der Modernität', in Garber and Rehm (eds), global benjamin 2, pp. 717-44; Hilde Heynen, Architecture and Modernity (Cambridge, MA: MIT Press, 1999), pp. 103-119; Tyrus Miller, “"Glass Before its Time, Premature Iron”: Architecture, Temporality and Dream in Benjamin's Arcades Project', in Beatrice Hanssen (ed.), Walter Benjamin and The Arcades Project (London: Continuum, 2006), pp. 240-258; Detlef Mertins, 'The Enticing and Threatening Face of Prehistory: 
a particularly austere version of the avant-garde discourse that interested Benjamin, but there is a more specific connection here as well: as Jean-Louis Cohen has described, Teige maintained a significant correspondence with both Giedion and, in particular, Behne.35 Finally, both had to work through a period of initial skepticism before becoming favourably disposed towards Surrealism. Thus Benjamin and Teige shared on the one hand an interest in architectural functionalism and its broader impact through the various cultural inflections of Constructivism, and on the other hand an interest in Surrealism that is initially hesitant yet increasingly powerful as the 1920 draw to a close.

Walter Benjamin and the Utopia of Glass', in Assemblage 29 (1996), 6-23; Pierre Missac, Walter Benjamin's Passages, trans. by Shierry Weber Nicholson (Cambridge, MA; MIT Press, 1995), chapter 6; McCole, Walter Benjamin and Antinomies of Tradition, pp. 184-85 and 229-30; and Susan Buck-Morss, The Dialectics of Seeing: Walter Benjamin and the Arcades Project (Cambridge, MA; MIT Press, 1989), pp. 124-31.

35 Jean-Louis Cohen, 'Introduction', in Teige, Modern Architecture in Czechoslovakia, pp. 27, 34, and 44. See also Rostislav Švácha, 'Before and After the Mundaneum: Teige as Theoretician of the Architectural Avant-Garde'; Eric Dluhosch, ‘Teige's Minimum Dwelling as a Critique of Modern Architecture'; and Klaus Spechtenhauser and Daniel Weiss, 'Karel Teige and the CIAM: The History of a Troubled Relationship', all in Dluhosch and Švácha (eds), Karel Teige, 190o1951, pp. 106-39, 140-93, and 216-55, respectively. It should be noted that Teige would have had little sympathy for Benjamin's interest in Scheerbart. 
While these scattered intellectual analogies may suggest no more than a general milieu of shared concerns, examination of Teige's early texts reveals more specific parallels. In 1925 Teige published a major essay called 'Constructivism and the Liquidation of "Art". The very title reveals Teige's interest in identifying the concerns of International Constructivism with what Benjamin in the artwork essay would call the 'Liquidierung des Traditionswertes am Kulturerbe' (GS 7, p. 354). Teige's description of a contemporary liquidation of art makes no pretence to originality. Offering reasoned diagnosis of present conditions rather than a bombastic rallying cry for the future, Teige merely claims to summarize what is being put into action by avant-garde circles in Moscow, Berlin, and elsewhere. Teige reflects theoretically on what he deems both a widely established fact and an epochal shift in how culture is produced: 'Constructivism is not some sort of passing aesthetic and artistic fashion [.... It is] an extremely broad and an absolutely international movement [...], the entrance into a new epoch of culture and civilization' (Výbor 1, p. 129). The primary characteristic of this emerging era, Teige claims, is that it transforms the category of art so radically that the very word becomes practically unusable. Teige puts the word 'art' in scare quotes in the very title of his essay and emphasizes that the term must not be understood in its standard sense: 'If we still use the word "art" today and perhaps for some time yet as a terminological aid, one must note that it does not mean for us sacred and sublime Art with a capital "A" [...], which the modern age has removed from its throne' (Výbor 1, p. 130). Disparaging the thinly disguised religious rhetoric he felt usually accompanied aesthetic discourse, Teige describes Constructivism as the liberation of art from theological functions and its emergence from the clouds 
of cultic veneration. He writes: 'We do not attach any sacral or cultic sublimity to art at all, we do not surround it with the smoke of holy incense' (Výbor 1, p. 130). The liquidation of art, therefore, returns it to solid ground: spectral images and holy haze give way to tangible, functional products. Several years earlier Teige had invoked Ehrenburg's formulation that 'the new art is not art', but in this essay he offers a redemptive re-definition of the term: "For us the term "art" [umění] comes from the verb 'to be able' [uměti] and its product is an artifact [umělost]. [...] Art is simply a manner of utilizing particular means for a particular function, and both means and function are more or less variable quantities' (Výbor 1, p. 130). Constructivism, in short, makes art once again useful-a tool to be grasped and applied towards the improvement of everyday life. Teige thus invokes classic Marxist rhetoric for de-bunking aesthetic fetishism: Constructivism extracts the rational kernel from the mystical shell. But it is not difficult to see in Teige's image of what Constructivism liquidatesthe cultic cloud of 'holy incense' keeping traditional artworks at reverential remove-also the hazy outline of Benjamin's notion of aura.

The transformation of art that drove Teige to his etymological reinvention of the term was fundamentally related to technical developments and, above all, to technical reproducibility. In 1922 he writes in one of his first major essays: 'Painting is not religion [...] it is primarily a craft. And as a craft it cannot ignore the impact of mechanical reproduction. It may be assumed that some day in an egalitarian socialist society pictures will be reproduced [rozmnožovány] by machine; this is already occurring partially through reproductions, which, more 
than originals, mediate the artistic-cultural relations of today'. ${ }^{36}$ This passage (practically simultaneous with Moholy-Nagy's telephone pictures, which it seems to parallel so closely), partially retains a traditional vocabulary of artistic production in its understanding of mechanical reproduction as a sort of craftsman's tool. But the concept of mechanical reproduction quickly proved stronger than such remnants. Less than a year later Teige wrote an essay explaining the phenomenon of the 'picture-poem' (obrazová báseň), an early form of photo-montage recently taken up by several members of Devětsil (including Teige himself, who coined the term) combining verbal elements and visual images into a sort of multi-media collage. 37 As if chased away by the technical requirements and innovative possibilities of this experimental genre, all references to art as handicraft disappear:

36 'Umění dnes a zítra', in Karel Teige and Jaroslav Seifert (eds), Revoluční sborník Devětsil (Prague: Večernice, 1922), p. 196.

37 On the genre of the picture-poem, see Matthew S. Witkovsky, Foto: Modernity in Central Europe, 1918-1945 (Washington, D.C.: National Gallery of Art, 2007), pp. 42-47; Karel Srp, 'Optical Words (Picture Poems and Poetism)', in Vladimír Birgus (ed.), Czech Photographic Avant-Garde, 1918-1948 (Cambridge, MA: MIT Press, 2002), pp. 56-72; Karel Srp, 'Karel Teige in the Twenties: The Moment of Sweet Ejaculation', in Dluhosch and Švácha (eds), Karel Teige, 190o1951, pp. 29-41; and Zdenek Primus, 'Obrazová báseň-entuziastický product poetismu', in Karel Srp and Michal Bregant (eds), Karel Teige, 1900-1951 (Prague: Galerie hlavního města Prahy, 1994), pp. 49-62. 
This fusion [of traditional genres in the picture-poem] will likely bring about sooner or later the liquidation (even if gradual) of traditional methods of painting and poetry. Picture-poems completely conform to contemporary requirements. Mechanical reproduction allows pictures to take book form. [...] Mechanical reproduction will bring about the popularization [zlidovění] of art securely and on a mass scale. The press [Tisk], not museums or exhibitions, mediates between artistic production and spectators. The old type of exhibition is dying out, for it too much resembles a gallery-like mausoleum. The modern exhibition must be a bazaar (a trade fair, a world exhibition). [...] Mechanical reproduction and the press will ultimately make originals useless-after all, we throw manuscripts into the garbage after they have been printed. ${ }^{3}$

Here Teige not only embraces the new media (the press and typographic pictures published in book form) that technical reproduction opened up and that he felt were bringing art objects closer to the masses. He was already stating in 1923 that technical reproduction made the very concept of an original obsolete-one of Benjamin's central and most celebrated claims. 39

${ }_{38}$ Karel Teige, 'Malîřství a poezie', in Štěpán Vlašín (ed.), Avantgarda známá a neznámá, Vol. 1 (Prague: Svoboda, 1971), p. 496, emphases in original.

39 One of the most famous picture-poems-the cover image for the 1922 avantgarde anthology Život II, co-designed by Teige with several other members of Devětsil-was reproduced in 1924 in the Berlin journal G. Richter's gloss on Teige and the Prague avant-garde (on the page facing Benjamin's translation of Tzara's article, see note 30), relays Teige's basic understanding of the function of 
Teige's comments on the transformations brought about by or instigated in modern forms of exhibition (as a bazaar or trade fair) further anticipate Benjamin's distinction between cult value and exhibition value in the artwork essay. Both authors describe the cultic origin of art in religious ritual and see such cultic function extending in secularized form into late nineteenth-century Aestheticism. In both accounts, cultic art (in all its historical forms) seeks out tight, inaccessible spaces: Teige writes of a 'mausoleum', Benjamin of prehistoric caves and the inner sancta of Greek temples or medieval cathedrals (GS 7, p. 358). Cultic art hides: Benjamin writes that 'der Kultwert als solcher drängt geradezu darauf hin, das Kunstwerk im Verborgenen zu halten' (ibid.). The event of viewing such art thus inherently becomes either initiatory rite or confirmation of privilege. This is why both Teige and Benjamin describe the trend towards exhibition value in modern art as the 'emancipation' or release of art, the opening up of such spaces of religious or aesthetic control and, therefore, as the counterpart to a broader egalitarian or progressive political shift.

the picture-poem: 'the title page of Zivot [sic] illustrated on p. 23 belongs to a series of Teige's "picture poems" that he, tired of the senselessness of oil painting-has produced for reproductive techniques in the framework of the book' (in Mertins and Jennings [eds], $G$, p. 140). To speculate that Benjamin might have reflected upon this a decade later may be too bold; yet it should be noted that the artwork essay does echo other concepts from $G$, such as Richter's term 'optical unconscious'; see Mertins and Jennings, 'Introduction', in Mertins and Jennings (eds), G, p. 16. 
The political implications of this shift from cult to exhibition value explain why Teige associates technical reproduction with a process of popularization. 40 Rather than seeing technology's intrusion into the realm of the aesthetic as a form of de-humanization or alienation, Teige emphasizes that this shift in fact brings art (with all the caveats he attaches to the term) closer to the masses. There are several aspects to his argument. The first is the obvious fact that technology enables broader, faster, and more thorough distribution of cultural products to the public (via reproductions and the like). But the more interesting aspect of Teige's notion of a popularization of culture involves the transformation inaugurated in art by its increased social proximity to the masses. Teige is less interested in the cultural edification of the masses than in the massification of culture; indeed, he is among the earliest theorists of the interwar avant-garde to embrace mass culture wholeheartedly. In 1922 he extolls 'westerns, Buffalo Bills, Nick Carter novels, sentimental novels, American movie serials and Chaplin's grotesques, amateur comedy theater, variété jugglers, wandering minstrels, clowns and acrobatic circus riders, Springtime folk celebrations, a Sunday football match' and claims that 'these literary forms-many of you will say: deformities-are nowadays the one and most characteristic popular [lidovou]

40 The Czech term Teige uses (zlidovění) is difficult to render in English. It not only describes popularization in the consumerist sense (as in 'popular culture') but also implies a process of 'humanization'. The central morpheme, lid, means 'people' both in the narrow sense of a nation and the wider sense of humanity in general (lidstvo). 
literature' (Výbor 1, p. 58). Teige greatly values mass culture's capacity to produce a positive reaction in its audience and contrasts this with some of the more obscure works of modernist production: he states that 'Alexander Blok's works could not approach the readership enjoyed by the anonymous authors of Buffalo Bill novels' and insists that the modern artist think long and hard why the masses respond spontaneously and positively to Chaplin, Sherlock Holmes novels, or the good soldier Švejk while remaining indifferent to Verlaine, Braque, and Picasso (all artists for whom he otherwise has enormous respect). ${ }^{41}$ Teige, in short, takes the position towards mass culture that would later so famously spark Benjamin's exchange with Theodor Adorno, who expressed great discomfort with what he felt to be Benjamin's 'romanticization' of the Chaplin grotesque and the 'laughter of the film spectator'.42 Just as Teige discovers new cultural forms in what others regard as deformities, Benjamin cautions in the artwork essay that 'es darf den Betrachter nicht irre machen, daß diese [mass culture] zunächst in verrufener Gestalt in Erscheinung tritt' (GS 7, p. 380). And just as Teige feels that popular culture exerts a positive, progressive emotional effect on the masses alienated from high culture, Benjamin emphasizes: 'Die technische Reproduzierbarkeit verändert das Verhältnis der Masse zur Kunst. Aus dem

41 Výbor 1, p. 58, and see also Teige, 'Umění dnes a zítra', p. 189. On such 'antimodernist' moments in Teige (and their imbrications in the notion of lidovost) see Zusi, ‘Tendentious Modernism’.

42 The relevant passage from their correspondence is reproduced in GS 1, pp. 1003-04. 
rückständigsten, z.B. einem Picasso gegenüber, schlägt es in das fortschrittlichste, z.B. angesichts eines Chaplin, um'.43

The privileged forum for such transformative encounters is film. In the artwork essay Benjamin compares film to the epic as a mode of collective reception.44 In 1922 Teige enthusiastically describes film as 'the most powerful fact of contemporary culture and civilization', 'the true lexicon of the new art', and even as 'a Bethlehem from whence comes the salvation of modern art'.45 What initially motivates Teige's interest in and identification of this new medium as a crucial phenomenon of modern culture is its mass appeal, the 'almost

$43 \quad$ GS 7, p. 374, emphasis in original. Benjamin connects this progressive reaction with the fact that jeder den Leistungen, die [die Technik des Films] austell[t], als halber Fachmann beiwohnt' ( $G S$ 7, p. 371). For Benjamin this engaged subject position has its paradigm in sports, especially what one might now call the 'Monday morning quarterback' attitude (Benjamin's example is newspaper boys leaning on their bikes and analyzing a bicycle race). Here, too, Teige's logic is similar when he claims that Poetist art 'must be obvious, passionate, and accessible just like sports, love, wine, and all delicacies' (Výbor 1, p. 121).

44 See $G S$ 7, p. 375 .

45 Teige, 'Umění dnes a zítra', pp. 190-91. In the final phrase Teige teasingly imitates a familiar Czech Christmas carol. In these passages, too, Teige conditions his claims with the caveat that the word 'art' does not quite fit these modern cultural phenomena. 
unconditional support and enthusiastic applause of the audience'.46 But after breathlessly listing the ways that film draws on and energizes various features of popular culture-American bars, novels about tropics or prairies, dancing halls, circuses, etc.-Teige suddenly connects the power of film with its nature as a medium utterly saturated with technology:

[Film contains] the pure power of modern poetry [poesie]. It has its precise form, which functions more perfectly than classical stanzas and the sonnets of the poets [...]. [I]n its origin from the optical discoveries of chronophotography and mechanical and chemical production it is an exemplar and model for all new art [...]. It is correct to say that the invention of the cinema has for us the same importance as the invention of the printing press for the renaissance: here too mechanical production distributes art to its spectatorship. [...] Yes, all modern artistic culture consists in and must consist in mechanical production [strojové výrobě]. 47

Teige places film at a crucial nodal point in the technical development of art and identifies it as the archetypal modern media. 48 In contrast to his statements

46 Ibid., p. 193.

47 Ibid., p. 193. Emphasis in original.

48 Teige thus presupposes a narrative about the historical development of art that focuses on nodal points associated with technological breakthroughs (e.g., the printing press or film), much as does Benjamin. For both thinkers these breakthroughs can be 'anticipated' before the necessary technological means to enact them exist. In an incidental but very Benjaminian comment, Teige describes the use of stained glass windows in Gothic cathedrals as a utopian 
about other visual media (such as the picture-poem quoted earlier), Teige writes here of technical production (výroba), not reproduction (reprodukce). This constitutes the privileged moment of film: it does not start with an original art object and subsequently make use of technology for its reproduction or distribution, but is rather from the outset a mass-produced product. Teige does not explicitly state here that film eliminates originals altogether, but his enthusiasm is based on film's status as a 'purely' cultural object that is simultaneously a product of technical production just like the cars, airplanes, and telephones Teige invokes to show how the achievements of engineers, though not intended as aesthetic object, have nonetheless trumped the pseudo-romantic selfindulgence of poets. Film thus provides Teige the crucial evidence for his argument that 'even standardized mechanical production gives rise to a new beauty' and thus that 'beauty is not the exclusive domain of so-called art'.49

anticipation of the use of projected, colored light for artistic purposes, a wishimage that required eight centuries for technology to provide the means for its fulfillment in cinema; see Teige, 'Poesie pro 5 smyslů', p. 207. Compare Benjamin's claim that 'es ist von jeher eine der wichtigsten Aufgaben der Kunst gewesen, eine Nachfrage zu erzeugen, für deren volle Befriedigung die Stunde noch nicht gekommen ist' ( $G S$ 7, p. 378). Teige of course is no more able to explain such historical anticipations in materialist terms than is Benjamin when discussing Dada.

49 Teige, 'Umění dnes a zítra', p. 190. 
To take stock then: by 1923 (1925 at the very latest), Teige's theoretical position entails the following points. Art is undergoing a radical transformation in modern society, so radical in fact that it barely makes sense to use the term at all; this transformation is inherently linked to the technical reproducibility of cultural objects; the saturation of cultural objects with technology erodes (and ultimately promises to destroy) the status of the original; traditional cultic functions of art, remnants from its originary association with religious ritual, are giving way to a libratory process releasing art into spaces where exhibition value and use value take on primary importance; these processes lead to an inescapable politicization of aesthetics and culture as these are brought closer to the masses and function as a source of social empowerment; the popularization of culture pushes the form of what is to be deemed art in the direction of mass culture; and film represents the most advanced stage of these developments, equal in impact to the invention of the printing press in the Renaissance.

Clearly, much of the basic argument of the artwork essay is contained here. To be sure, Benjamin's formulations are more subtle, philosophically more resonant, and conceptually more suggestive. Further, writing in 1935 allows (indeed forces) Benjamin to take several of these arguments further than Teige.50

50 For example, while Teige's texts are suffused with the imperative to politicize aesthetics, fascism obviously does not present the urgent threat for him in 1925 that it does for Benjamin in 1935. By the mid-1930s Teige also focused on critiquing the aestheticization of politics in Nazism-and, he grudgingly admits, to an increasing degree in the Soviet Union as well. By this time, however, the 
What stands revealed as an obdurate phantasm, however, is the 'strong thesis' regarding Benjamin's heresies: that is, that when making these arguments in 1935 Benjamin puts forward an original and shocking line of thought. These arguments were not only implicit in the activities of Dadaists and Constructivists during the later 1910 s and early 1920 , they received theoretical articulation by the mid-1920s at the latest. By the time of Benjamin's artwork essay, in fact, the liquidationist discourse had even begun to reverse direction: rather than aesthetic theory attempting to articulate the implications of raw cultural practice, art objects had begun to illustrate explicitly what were already familiar theoretical tenets. If Benjamin had wished to embody his central thesis about the liquidation of aura in a visual image, he could hardly have done better than did Jaromír Funke, one of the leading experimenters in Czech interwar photography. Funke's quasi-Surrealist photo series Time Persists, created between 1930 and 1934, contains the striking image of a sculptural angel reaching upwards and holding a wreath resembling a halo (Figure 1). The photograph makes expert use of the vocabulary of pseudo-auratic pictorialism: hazy light, soft focus, melodramatic gesture. Yet these elements are starkly ironic, since foreshortening makes a distant factory smokestack appear to be right in front of the winged angel. This juxtaposition transforms the gesture: the expression of striving becomes an awkward stretch, an attempt to dump the halo of art into the inconveniently tall furnace of industry.

technological reproducibility of culture was no longer the vital issue it had been for him in the 1920 . 


\section{Aura and Ornament}

By 1935, therefore, the liquidationist claims of the artwork essay were not the shocking cutting edge but rather the Jüngstvergangene, the most recent past, of avant-garde thought. That is decidedly not to say they were passé-indeed the political urgencies of the mid-1930s most likely reinforced the authority of such liquidationist claims as a weapon against false aestheticization. But arguments regarding the effect that technological change had wrought in the structure, function, and reception of artworks had consolidated into a common line that could be compactly invoked, would be easily recognized, and enjoyed widespread acceptance by many of those participating in the theoretical evolution of the European avant-garde to that time. From this angle, what stands out more prominently in the artwork essay is not the liquidation of aura thesis but rather the sustained attention Benjamin devotes to the structure of auratic art itself (which, for a thinker such as Teige, was primarily of negative interest). Even this observation, to be sure, has a hallowed past, and underlies two prominent approaches to Benjamin's concept of the aura: the first comprises the many fruitful analyses of Benjamin's 'ambiguous attitude' towards modernity or the way he straddles the 'antinomies of tradition', while the second encompasses accounts of Benjamin's 'redemptive' critical practice, that is, the claim that while Benjamin embraces the anti-auratic tendencies of avant-garde cultural practice he does so in the name of 'rescuing' a form of experience closely identified with 
auratic art.51 The 'ambivalence' approach admits an unresolved inconsistency at the heart of Benjamin's thought but has also grounded his appeal for many readers for whom disillusionment with avant-gardism or high Modernism is paramount. The 'redemption' approach grants Benjamin greater theoretical consistency but implicitly links him with a decidedly utopian strain in avantgarde thought. Both approaches, however, leave the liquidationist claims unchallenged as the radical core of the artwork essay. Whether Benjamin embraced those claims with a wistful glance backwards or with all too great expectations, they generate the shock value and place the essay at the forefront of avant-garde theoretical speculation at that time.

51 For two important instances of the 'ambivalence' thesis, see Beatrice Hanssen, Walter Benjamin's Other History: Of Stones, Human Beings, and Angels (Berkeley: University of California Press, 1998), p. 50; and McCole, Walter Benjamin and the Antinomies of Tradition, passim. Other commentators follow similar logic but with different terminology: thus Diarmuid Costello writes that 'Benjamin's attitude is marked not so much by ambivalence as by a double-edged response. He welcomes and mourns its passing simultaneously; his remarks about aura manifest both a "liquidationist" and an "elegiac" undertow'; Diarmuid Costello, 'Aura, Face, Photography: Re-Reading Benjamin Today', in Benjamin (ed.), Walter Benjamin and Art, p. 178. The locus classicus for the 'redemption' approach is Habermas, 'Consciousness-Raising or Rescuing Critique', esp. pp. 106-08. See also, e.g., Lindner, 'Benjamins Aurakonzeption', p. 232. 
The final section of this article will suggest a different perspective on the artwork essay by applying to it Benjamin's own concept of the wish-image. The application must remain to a degree heuristic, for in two fundamental respects Benjamin's understanding of the wish-image, as put forward in his 1935 'Exposé' for the Passagen-Werk entitled 'Paris, die Hauptstadt des XIX. Jahrhunderts' (written just a few months before the first version of the artwork essay), resists precise application to the material of the artwork essay. The first reason is that Benjamin uses the wish-image as a tool for historical analysis: wish-images are necessarily invisible to those under their thrall and reveal themselves only to observers at a temporal remove. To describe a wish-image holding sway over one's own present is, in a sense, equivalent to an attempt to lift oneself up by one's own bootstraps. None the less, I argue that this framework offers a more persuasive response to the internal tensions of the artwork essay than the 'ambivalence' approach: Benjamin is both under the thrall of liquidationist logic and critical of some of its fundamentally utopian impulses (as further comparison with Teige will reveal). In other words, Benjamin's position should be understood less as elegiac ambivalence concerning the vanishing of aura than as veiled suspicion concerning the liquidationist claim that aura will vanish. Second, liquidationist logic requires re-tooling the concept of the wish-image, which Benjamin developed primarily in consideration of the historicist wishimagery of the nineteenth century. In the 'Exposé' Benjamin described wishimages as images 'in denen das Neue sich mit dem Alten durchdringt. [...] [I]n diesen Wunschbildern [tritt] das nachdrückliche Streben hervor, sich gegen das Veraltete-das heißt aber: gegen das Jüngstvergangene-abzusetzten. Diese 
Tendenzen weisen die Bildphantasie, die von dem Neuen ihren Anstoß erhielt, an das Urvergangne zurück' (GS 5, p. 46-47). Striving against the outmodedequated here with the most recent past-wish-images reach back to the primal visual vocabulary of Urgeschichte, allowing the new to appear infused with utopian force. Yet this gesture against the grain of temporality, the mingling of the new with images drawn from the primal past, is precisely what the liquidationist position forbids. While a compulsive drive to distance itself from the Jüngstvergangene most certainly characterizes liquidationist logic, this is performed in the name of a temporal 'purity' that makes the admixture of archaic forms anathema.

For this reason the liquidationist wish-image must take spatial rather than temporal form. The vanishing point Benjamin used to describe the subject of the artwork essay to Horkheimer provides an apposite conceptual figure, for it connotes the hypothetical end-point of the developmental process for which the withering of the aura is the major symptom. While liquidationist logic stringently denies itself the right to meld the new with the archaic, the wish-image of the vanishing point does posit a comparable series of fused oppositions, such as integration and autonomy, utility and purposelessness, or 'Ernst und Spiel' (GS 7, p. 359). What 'vanishes' with the aura is the line separating the terms in these oppositions. Perhaps no theorist of the avant-garde pursued this wish-image as systematically as Teige, whose programme in the 1920 s represents a series of attempts to articulate the continuity between stringent functionalism and ludic 'Poetism'. Further comparison with Teige thus helps determine the degree to which the artwork essay is beholden to the wish-image of the vanishing point. 
Benjamin's most impassioned defense of what might be called the liquidationist 'standard line' in fact appears in a text published two years before he began work on the artwork essay. His 1933 article 'Erfahrung und Armut', celebrating the 'new barbarians' who have responded to the experiential poverty of modernity not with despair but rather with a drive 'von vorn zu beginnen; von Neuem anfangen' (GS 2, p. 215), invokes a series of Constructivist truisms in rhetoric that Teige (and other proponents of Constructivism) had been using since the early 1920s. For example, Benjamin decries the architecture of the bourgeois era as representing 'das grauenhafte Mischmasch der Stile' and presupposing a 'hergebrachten, feierlichen, edlen, mit aller Opfergaben der Vergangenheit geschmückten Menschenbilde'. The new barbarians, by contrast, represented 'constructers' who, committed to the ideals of logical transparency, egalitarian social re-structuring, and sober commitment to the contemporary age, would clear the tables in the manner of Descartes. $5^{2}$

${ }^{2} G S$ 2, p. 215. 'Erfahrung und Armut' was originally published in the Prague paper Die Welt im Wort. Teige, as far as I know, never commented on the piecesurprising given the proximity to his own concerns. This silence might indicate that he found Benjamin's liquidationist claims to be conventional or even retrograde (he would certainly have raised an eyebrow at Benjamin's praise of Scheerbart). On Cartesianism and the transparency ideal within Constructivism, see Daniel Herwitz, Making Theory/Constructing Art: On the Authority of the Avant-Garde (Chicago: University of Chicago Press, 1993), chapter two. 
In language that sounds perhaps intentionally crude in a text by Benjamin but that hews closely to Constructivist logic, Benjamin associates the radical gesture of the barbarian constructers with the transparency and clean surface of glass architecture, invoking specifically the architecture of Adolf Loos, Le Corbusier and the Bauhaus as well as (more idiosyncratically) the novels of Paul Scheerbart.53 In a sentence anticipating the central term of the artwork essay a few years later Benjamin writes: 'Die Dinge aus Glas haben keine "Aura”. Das Glas ist überhaupt der Feind des Geheimnisses. Es ist auch der Feind des Besitzes' (GS 2, p. 217). Here Benjamin displays no ambivalence: aura must go. The vanishing of the aura is not merely a developmental necessity that one might welcome or decry, but a programme to be actively pursued, since sweeping away the suffocating historical detritus of 'culture' (Benjamin himself uses scare quotes) inaugurates radical social reorganization, hostile to the bourgeois values of individualism and private property. The rhetorical similarity of this text to an almost exactly contemporaneous text on architectural functionalism and urban planning by Teige stands out starkly in the respective critical descriptions of the 'bourgeois interior'. One year earlier Teige wrote:

53 Indeed at times glass architecture becomes for Benjamin (as for Teige as well) a competitor to film as archtypal modern technological medium: see, e.g., Benjamin's note in the Passagen-Werk that 'es ist das Eigentümliche der technischen Gestaltungsformen (im Gegensatz zu den Kunstformen), daß ihr Fortschritt und ihr Gelingen der Durchsichtigkeit ihres gesellschaftlichen Inhalts proportionell sind. (Daher Glasarchitektur.)' (GS 5, 581, emphases in original). 
A room of the eighties and nineties of the last century is a stuffy place, full of dust and cobwebs hidden in inaccessible nooks and crannies, full of germs and stale air. Furniture is not there for the purpose of living but only for representation and a show of opulence: here we find vitrines, jardinières, huge clocks, pedestals, thrones instead of chairs, ceramic turtles and plaster busts (Napoleon, Dante, Tyrš, and Fügner), embroidered coverlets and cushions, real or imitation oriental carpets and tiger hides, paper palms, glass flowers as lamps, appliqués, batiques, and so on, and so on. The textile of choice is velvet: germs and dust thrive in this material that cannot be laundered or cleaned. Ornamentation, naturally, is the correlative accompaniment to such accommodation and furnishings. 54

In ‘Erfahrung und Armut’ Benjamin wrote:

Betritt einer das bürgerliche Zimmer der 8oer Jahre, so ist bei aller 'Gemütlichkeit', die es vielleicht ausstrahlt, der Eindruck 'hier hast du nichts zu suchen' der stärkste. Hier hast du nichts zu suchen-denn hier ist kein Fleck, auf dem nicht der Bewohner seine Spur schon hinterlassen hätte: auf den Gesimsen durch Nippessachen, auf dem Polstersessel durch Deckchen, auf den Fenstern durch Transparente, vor dem Kamin durch den Ofenschirm. 55

54 Karel Teige, The Minimum Dwelling, trans. by Eric Dluhosch (Cambridge, MA: MIT Press, 2002), pp. 164-65, translation modified. Czech original: Karel Teige, Nejmenší byt (Prague: Václav Petr, 1932), p. 155.

55 GS 2, p. 217. Like Teige, Benjamin focuses on velvet as the characteristic material for such interiors, emphasizing its ability to retain traces (Spuren) of the inhabitants' lives (see also GS 5, p. 294). A largely similar passage appears in the 
Thus in 'Erfahrung und Armut' Benjamin aligned the vanishing of the aura thesis with a functionalist critique of ornament: aura is ornamental, a historical trace now become superfluous, unhygienic, and thus pernicious. The architectural environments favoured by late bourgeois society clung desperately to the auratic in the form of external ornamentation and interior plush. The only proper response to the conditions of modernity is to sweep both ornament and aura away. In a sentiment Teige would have seconded without reserve, Benjamin cites Brecht's exhortation to “"Verwisch die Spuren!"” 56

Yet elsewhere Benjamin grants precisely these same traces privileged cognitive value. In the Passagen-Werk Benjamin does not unvaryingly align, but also at times contrasts his approach to that of Siegfried Giedion:

"Abgesehen von einem gewissen Haut-goût-Reiz, sind die künstlerischen Drapierungen des vergangenen Jahrhunderts muffig geworden” sagt Giedion. [...] Wir aber glauben, dass der Reiz mit dem sie auf uns wirken,

Denkbilder in GS 4, p. 427-28. In the 'Kleine Geschichte der Photographie' Benjamin invokes similar interior details as Teige to describe the later nineteenth-century photography ateliers 'mit ihren Draperien und Palmen, Gobelins und Staffeleien [...], die so zweideutig zwischen Exekution und Repräsentation, Folterkammer und Thronsaal schwankten' (GS 2, p. 375). He then contrasts this with Atget's 'Befreiung des Objekts von der Aura' in a vocabulary of hygiene and 'disinfection' again reminiscent of Teige (GS 2, p. 378). ${ }^{6} G S$ 2, p. 217; see also GS 4, p. 427. 
verrät, dass auch sie lebenswichtige Stoffe für uns enthalten-nicht zwar für unser Bauten, wie die konstruktiven Antizipationen der Eisengerüste es tun, wohl aber für unser Erkennen wenn man will für die Durchleuchtung der bürgerlichen Klassenlage im Augenblick da die ersten Verfallszeichen in ihr erscheinen. Politisch lebenswichtige Stoffe auf jeden Fall; das beweist die Fixierung der Sürrealisten an diese Dinge genau so wie ihre Ausbeutung durch die gegenwärtige Mode. Mit anderen Worten: genau so, wie Giedion uns lehrt, aus den Bauten um 1850 die Grundzüge des heutigen Bauens abzulesen, wollen wir aus dem Leben [und] aus den scheinbar sekundären, verlorenen Formen jener Zeit heutiges [Leb]en, heutige Formen ablesen (GS 5, p. 572).

This passage points to a crucial logical pivot in the Passagen-Werk, one that has fundamental implications for the artwork essay as well.57 More important here than the word 'Reiz'-which can too easily be taken as a coded sigh or ambivalent 'verweile doch, Du bist so schön'-are the phrases 'Durchleuchtung der bürgerlichen Klassenlage' and 'politisch lebenswichtige Stoffe'. These mark the cognitive force Benjamin identifies in outmoded ephemera. Benjamin pivots here from the logic of a Constructivist to that of the 'ragpicker', and he uses the concept of montage to connect these two rhetorical constellations. He sounds like a good Constructivist when he states that it is crucial 'das Prinzip der Montage in der Geschichte zu übernehmen. Also die großen Konstruktionen aus

57 Hansen discusses Benjamin's 'position-switching' between different texts (Cinema and Experience, p. 81). Yet this particular pivot exists within the Passagen-Werk material, suggesting that the juxtaposition is not mere strategic convenience. 
kleinsten, scharf und schneidend konfektionierten Baugliedern zu errichten' (GS 5, p. 575). This passage picks up on his identification of the Eiffel Tower (an iconic artifact for Constructivists such as Teige) as 'die früheste Erscheinungsform des Prinzips der Montage' (GS 5, p. 223), constructed from millions of minute, precisely coordinated pieces. The constructive process, as well as the breathtaking new vistas revealed from atop these structures, are the proper reserve of the engineer and the high-steel worker. 58

But montage also appears as the method of the ragpicker: 'Methode dieser Arbeit: literarische Montage. Ich habe nichts zu sagen. Nur zu zeigen. Ich werde nichts Wertvolles entwenden und mir keine geistvollen Formulierungen aneignen. Aber die Lumpen, den Abfall: die will ich nicht inventieren sondern sie auf der einzig möglichen Weise zu ihrem Rechte kommen lassen: sie verwenden' (GS 5, p. 574). Here the materials for montage are not the precisely constructed Bauteile of the constructer but rather the loose detritus gathered by the historian as ragpicker. While Benjamin never states this explicitly, the 'ragpicker model' effects a radical re-evaluation of liquidationist logic: the dusty carpets and mouldering tiger pelts, the flower-shaped lamps and ceramic turtles are no longer

58 See GS 5, p. 218 and 572. Benjamin further connects this image of the 'panoramic view' from atop modern structures with the ideal of philosophical 'Anschaulichkeit' (GS 5, p. 575). 
to be thrown out with an indignant cry of 'Verwisch die Spuren!' but rather are to be gathered and explored as a wilderness of cognitive raw material.59

This pivot should not be dismissed as ambivalence, confusion, or a curiosity resulting from Benjamin's tendency to think in images, because in fact it harbours a two-fold critique of the liquidationist logic that the artwork essay is understood to champion. Nor should this critique be explained away as ensuing from the distinction between the Passagen-Werk as analysis of historical, and the artwork essay as analysis of contemporary phenomena. Rather these claims in the Passagen-Werk reveal Benjamin's wariness of, first, an ideology of progress and, second, a dubious holistic tendency lurking within the liquidationist discourse invoked in the artwork essay.

Again, comparison with Teige is revealing. Discussing the emergence of modernist architecture in Czechoslovakia, Teige emphasizes its origin in engineering works and in the development of iron and glass as construction materials in the nineteenth century. He points to the immature, hybrid nature of the earliest products of the engineers: the first railway on the continent, designed by František Antonín Gerstner and constructed between Linz and České Budějovice in 1825-1828, was still drawn by horses and the railcars resembled stagecoaches; cast-iron bridges and functional structures around mid-century

59 Indeed such a landscape of 'geheime Affinitäten: Palme und Staubwedel, Föhnapparat und die Venus von Milo', stands at the outset of Benjamin's earliest notes for the Passagen-Werk (GS 5, p. 993). 
still utilized Neo-Gothic forms. ${ }^{60}$ For Teige, such outdated forms are senseless except insofar as they offer partial glimpses of coming architectural practices. The 'horrid iron Gothic' (Modern Architecture, 67) merely documents the historical fetters holding the imagination captive; one must look through such phenomena in order to perceive the gradual emergence of 'authentic' forms of modern construction. Benjamin echoes this sort of rhetoric often enough (for example in GS 5, p. 46, or in most of section 'F' of the Passagen-Werk). Yet when he discusses the hybrid forms assumed by 'zu früh gekommenes Glas, zu frühes Eisen'-such as an early design for a locomotive that would run on 'feet' like a horse, or plans to have steam-cars run on granite streets rather than iron tracks (GS 5, pp. 211, 217 and 218)-they subtly transform into documents not just of torpor and fear but also of creativity and longing. Benjamin rejects historical narratives that cast an entire era as embodying either a 'not yet' or cultural decrepitude: 'Das Pathos dieser Arbeit: es gibt keine Verfallszeiten. Versuch, das neunzehnte Jahrhundert so durchaus positiv anzusehen wie ich in der Trauerspielarbeit das siebzehnte mich zu sehen bemühte. Kein Glaube an Verfallszeiten' (GS 5, p. 571). His argument is not simply that one must painstakingly analyse the 'Traumschlaf' of the nineteenth century in order to wake from the phantasmagoria established under early capitalism. Rather, one

6o See Teige, Modern Architecture in Czechoslovakia, 60-67. 
must bracket (in an analogy to psychoanalytic method) the rigid 'Gegensatz von Schlaf und Wachen' itself. ${ }^{61}$ Benjamin writes:

Es ist sehr leicht, für jede Epoche auf ihren verschiedenen 'Gebieten' Zweiteilungen nach bestimmten Gesichtspunkten vorzunehmen, dergestalt dass man auf der einen Seite der 'fruchtbare', 'zukunftsvolle', 'lebendige', 'positive', auf der andern der vergebliche, rückständige, abgestorbene Teil dieser Epoche liegt. [...] Aber jede Negation hat ihren Wert andererseits nur als Fond für die Umrisse des Lebendigen, Positiven. Daher ist es von entscheidender Wichtigkeit, diesem, vorab ausgeschiednen, negativen Teile von neuem eine Teilung zu applizieren, derart, daß [...] auch in ihm von neuem ein Positives and ein anderes zu Tage tritt als das vorher bezeichnete. Und so weiter in infinitum, bis die ganze Vergangenheit in einer historischen Apokatastasis in die Gegenwart eingebracht ist (GS 5, p. 573).

The markedly theological term apocatastasis might suggest that here we have tripped upon the often noted antagonism in Benjamin's thought between the mystical and the materialist, the redemptive and the radical. But Benjamin's criticism of a crassly 'black-and-white' projection of history, and his mathematical image of an integral calculus that would sharpen the image, are in

${ }^{61} G S$ 5, pp. 494 and 492. Similarly, Benjamin replaces the traditional Marxist trope of base/ superstructure (with its insidious tendency to reduce 'culture' to 'ideology' or 'reflection') with a concept of 'expression' (Ausdruck) drawn from psychological and psychoanalytic practice. See GS 5, pp. 494-95, as well as his replacement of the 'base/superstructure' vocabulary with that of 'consciousness/unconscious' in the 'Exposé' (cf. GS 5, pp. 1224-255 and 46-477). 
at least one sense perfectly compatible with his materialist project: they warn against reading the past as a narrative of progress towards the present. When Benjamin shortly afterwards describes his aim as 'einen historischen Materialismus zu demonstrieren, der die Idee des Fortschritts in sich annihiliert hat' (GS 5, p. 574), he thus sets himself in contrast to precisely the form of historical materialism Teige pursues with his narrative of progressive 'erasure' of regressive historical traces over the course of the nineteenth century. In other words, liquidationist discourse risks positing a fixed telos and then reading the past as linear progress towards that endpoint: an endpoint at which fundamental diremptions between structure and ornament, function and aesthetics, truth and ideology, indeed matter and spirit, are presumed to vanish.

The charge of progressivism within liquidationist logic is thus inseparable from that of incipient holism. The project of 'wiping away the traces' strives for the sheer integration of opposites: what is posited at the vanishing point is a smooth, pure, transparent abstraction. The revised version of Teige's second 'Poetist manifesto' (1930) expresses with particular force this utopian ideal of integration through a reconfigured understanding of 'poesie' as the fundamental human creative/constructive drive:

The new poesie, as advanced schooling for the new human being, as a game [hra] of colours and lights, sounds and movements, is not a disinterested game: every game constitutes training and cultivation of particular instincts and is adapted to their functions. [...] The single, multi-faceted function of poesie as understood and prepared through Poetism is to endow, saturate, and reawaken human sensibility, to develop human capacities, whether 
sensory, sensual, or emotional [...]. Poetry for all senses: not l'art pour l'art, but rather a significant social function for the construction of the socialist world. Therefore: Poetism as the overcoming of the antagonism between poem and world, a new synthesis of poem and world, a synthesis of construction and poem [stavby a básně]. [...] This is the vanishing point in the Poetist perspective. 62

Teige's vanishing point, in contrast to Benjamin's, marks a point in the future: an ideal to be achieved, a prognosis to be fulfilled. This vanishing point constitutes the liquidationist wish-image. The foreground in Teige's image is his present moment, and the perspective he describes imagines development along a straight line into the future. At the endpoint of this progression, aura-in the negative sense Benjamin channeled in 'Erfahrung und Armut'-will have vanished.

Set against this wish-image, the conceptual tensions inhabiting the artwork essay-especially when juxtaposed to relevant claims in the PassagenWerk-no longer appear as ambivalence or elegiac mourning over the vanishing of the aura. The 'ornamental' historical detritus Benjamin wishes to utilize and thereby 'zu ihrem Rechte kommen lassen' maintains its heterogenous, fragmentary, and supplemental character, and thereby overtly flaunts the sacrosanct Constructivist image of peeling away the decorative husk (Hülle) to

62 'Poesie pro 5 smyslů', pp. 236-37. The parallel here to Benjamin's discussion of film as a 'Testleistung', which ultimately aims to ensure inhabitants of a technologized world 'eines ungeheueren und ungeahnten Spielraums', is evident (GS 7, pp. 365 and 376). See the discussion in Hansen, Cinema and Experience, chapter five. 
reveal a structural core (Kern) and thus to arrive at 'authentic' modern form. To be sure, this impulse in the Passagen-Werk returns to formulations from earlier periods in Benjamin's thought. In the 1930 report on hashish Benjamin had written: 'Vielmehr ist das Auszeichnende der echten Aura: das Ornament, eine ornamentale Umzirkung in der das Ding oder Wesen fest wie in einem Futteral eingesenkt liegt' (GS 6, p. 588). And in his essay on Goethe's Wahlverwandschaften from the early 1920 s he had written: 'der schöne Schein ist die Hülle vor dem notwendig Verhülltesten. Denn weder die Hülle noch der verhüllte Gegenstand ist das Schöne, sonder dies ist der Gegenstand in seiner Hülle' (GS 1, p. 195). Here Benjamin posits cognitive-aesthetic activity not as the extrication of a bare, 'true' structure from the disguise hiding it, but as examination of a veil that cannot be removed without destroying the truth 'behind' it. These earlier formulations are in part informed by dubious sources, yet it would be misguided to conclude Benjamin's retention of such impulses is simply a regressive hold-over from earlier days. ${ }^{63}$ For they return in his later

${ }_{63}$ Hansen discusses how Benjamin's concepts of semblance (Schein) and the veil (Schleier) are indebted to his surprising infatuation with the writings of Ludwig Klages (Cinema and Experience, pp. 115 and 124). On the echoes of Benjamin's earlier theory of beauty in the later concept of aura, see Smith, 'A Genealogy of "Aura", pp. 108-09. Benjamin himself seems aware of the need for selfcorrection: in the list of tainted art-historical concepts he claims the artwork essay will invalidate, 'Stil' in the first version is replaced in the second version by 
writings as implicit critique of the progressivist and holistic tendencies of liquidationist logic.

So what does this mean for the artwork essay, which undeniably invokes the liquidationist logic Benjamin equally undeniably questions? A response may lie in a single word. In the crucial section of the artwork essay where Benjamin defines aura and outlines the process of its decline, he writes: 'Und wenn die Veränderungen im Medium der Wahrnehmung, deren Zeitgenossen wir sind, sich als Verfall der Aura begreifen lassen, so kann man dessen gesellschaftliche Bedingungen aufzeigen' (GS 7, p. 354). The key word is 'Wahrnehmung'. Benjamin's argument in the artwork essay for the historicity of sense perception is well known: the human sensorium is not simply a natural or biological given but is historically determined as well (see $G S$ 7, p. 354). The idea that different historical periods generate different modes of interaction between individuals and the reality surrounding them was neither new (the notion is prominent in Marx) nor unusual (the quotation from Teige above exemplifies the absorption of this idea within avant-gardist rhetoric). Benjamin's invocation of this thesis has generally been understood as a component of the claim that aura is a historically contingent category rather than an intrinsic property of art; the historical shift of which reproducibility is emblematic, therefore, makes aura vanish because it no longer complements the prevailing structure of human perception. In short: aura

'Geheimnis'-a key term in his Wahlverwandschaften essay (cf. GS 1, p. 435 and $G S$ 7, p. 350). 
is revealed as an ideological category in the process of being 'shed'. ${ }^{64}$ But there is another aspect to Benjamin's attention to perception here that has largely escaped notice. For Benjamin does not in fact state that the contemporary shift in the mode of perception reveals aura to be 'false' and thus results in its withering (which would be Teige's position). Rather he claims that the contemporary shift in the mode of perception can be 'comprehended' through the idea of the vanishing of the aura. The decline of the aura, in other words, is not necessarily an objectively 'true' development, but it is a necessary perception. Indeed, to regard aura as vanishing is the hallmark of the contemporary mode of perception: 'Die Entschälung des Gegenstandes aus seiner Hülle, die Zertrümmerung der Aura, ist die Signatur einer Wahrnehmung, deren "Sinn für das Gleichartige in der Welt" so gewachsen ist, daß sie es mittels der Reproduktion auch dem Einmaligen abgewinnt' (ibid., p. 355). Not a historical

64 See, for example, Joel Snyder's summary of the 'aura as ideology' argument: 'An account of perception that fails to deal with ideology-with the stimulative capacity of ideas-will necessarily fail to explain why various qualities are attributed to objects and perceived as properly belonging to them, i.e., perceived as real properties of objects. Thus, for example, the perceived aura of objects has no immediate physical counterpart outside the human brain and cannot be explained biologically'; Joel Snyder, 'Benjamin on Reproducibility and Aura: A Reading of "The Work of Art in the Age of its Technical Reproducibility", in Gary Smith (ed.), Benjamin: Philosophy, Aesthetics, History (Chicago: University of Chicago Press, 1989), pp. 158-74 (p. 164). 
fact, but 'die Signatur einer Wahrnehmung'. This formulation pointedly skirts the question whether aura is 'truly' withering, and thus whether in the future we will arrive at the point where it has vanished completely, but does confirm that such a conviction is the defining characteristic of the contemporary mode of perception.

'Die Signatur einer Wahrnehmung': here lies the distinction between Teige and Benjamin, between prognosis and diagnosis, between liquidationist logic and depiction of a wish-image. The decisive point is not that Benjamin perceives aura to be vanishing: it is that he cannot help but perceive aura to be vanishing. This unavoidable perception is a wish-image that Benjamin both shares and recognizes as historically conditioned. Saturated with utopian energy, the wishimage underlies the artwork essay; yet that does not prevent Benjamin from surreptitiously imagining the Modernist monuments of steel and glass as ruins even while they are being built. 